Dr Pidd put forward the case for training in peripheral hospitals to continue. Psychiatric services in most of the country are still based in regional mental hospitals, and these hospitals provide trainees with the opportunity to obtain wide experience and undertake more responsibility, as well as better training in the care and rehabilitation of long-stay patients. She also emphasised the value of trainees to these hospitals as a stimulus to the maintenance of high standards. She argued that with active and enthusiastic tutors, aware that junior posts exist primarily for training rather than service, the peripheral psychiatric hospitals have much to offer trainees. The ensuing discussion indicated general agreement among trainees that we would not wish to lose the opportunities for training outside the teaching hospitals. The advantages of greater flexibility in training schemes are clear.

D. Craufurd
I. Davidson
N. Sumpson

North West Division

\title{
Autumn Quarterly Meeting, 1985
}

The Autumn Quarterly Meeting was held at Friends House, Euston, London NWI, on 14 and 15 November 1985 under the Presidency of Dr Thomas Bewley.

\section{Registrar's Report}

President, ladies and gentlemen, among the items that I shall report on today, there are two that I should like to emphasise particularly. These are the new Membership Examination and the forthcoming Code of Practice document from the Mental Health Act Commission.

Council has sat once since our Annual Meeting and a large part of the session was spent discussing the Report of the Working Party on the Review of the MRCPsych Examination. This Report, produced under the Chairmanship of Professor R. Cawley, containing detailed proposals for a new Membership Examination, had been accepted by the Court of Electors at a special meeting held in July. Council welcomed the Report, which had been prepared after three and a half years of careful deliberation. It was agreed that preparation should commence for its introduction in 1987. A shortened version of this Report will be appearing in the Bulletin and as from today copies are available from the Examinations Office at the College (could you please send an A4 self-addressed envelope).

The DHSS has issued a review of community nursing. The College has prepared detailed comments on this review and these are available from the College.

The Social Services Committee (chaired by Rence Short) published its Report into Community Care last March. The College had prepared written evidence and presented oral evidence to the Committee. We are now in the process of implementing some of the recommendations in the final Report, particularly Recommendation 78 concerning mental handicap services and Recommendations 79 and 80 concerning community psychiatric nurses. If any member of the College would like to send me their comments on the recommendations, and these three in particular, I should be very grateful.

We have also prepared written evidence to another important inquiry, namely the Social Services Committee's Inquiry into the Prison Medical Service. We have been invited to present oral evidence as well, which we shall give on 4 December at the House of Commons.

There are three documents from the Mental Health Act Commission that I should like to mention: (1) Its Biennial
Report; (2) The paper on Consent to Treatment (which I wish to emphasise is merely a consultation document); and (3) The Code of Practice.

We have been informed that we shall probably receive the Mental Health Act Commission's draft Code of Practice at the very beginning of 1986 . In view of the importance of this document and the relevance it will have to all psychiatrists, as well as other physicians, the President made a special request to the DHSS for a longer period of consultation than that which is normally given. We understand that we shall now have six months in which to prepare our comments. A Special Committee of Council has already been convened to collate and prepare the College's response. We shall, on receipt of the draft Code, immediately send it out to the Divisions and relevant College Committees. The Sections, together with general psychiatrists, are represented on the Special Committee, which will be chaired by the President. If any member wishes to comment on any aspect of the draft Code, I would be grateful to receive their comments, within one month, if possible, of its publication. The Special Committee will also comment on the Commission's Biennial Report and the Commission's paper on Consent to Treatment.

Council is discussing the possibility of preparing a joint statement with the Royal College of General Practitioners which will contain interim arrangements for the appointment of Section 12 approved doctors, until such time as the College's criteria can be achieved. The Public Policy Committee have been asked to consider this and report back to Council.

The Research Committee will be setting up an ECT Sub-Committee, which, among other things, will revise and up-date the 1977 ECT Guidelines prepared by the College.

The College has installed a telephone answering service which operates after $6.00 \mathrm{pm}$. I hope members will take advantage of this service.

Finally, the results of the recent elections Dr Anne Bolton has been elected as Vice-President; Professor Gelder and Dr Dick have been elected onto the Executive and Finance Committee. Dr William Boyd has been appointed by Council as Deputy Treasurer. Professors Schapira, Seager and Sims have been re-appointed as Sub-Deans.

R. G. Priest, Registrar 